\title{
Association between a genetic variant in the serotonin transporter gene (SLC6A4) and suicidal behavior in patients with schizophrenia
}

Eva Lindholm Carlström ${ }^{1 *}$, Peter Saetre ${ }^{1}$, Anders Rosengren ${ }^{2}$, Johan H Thygesen², Srdjan Djurovic ${ }^{3}$, Ingrid Melle ${ }^{3}$, Ole A Andreassen ${ }^{3}$, Thomas Werge ${ }^{2}$, Ingrid Agartz ${ }^{1,4,5}$, Håkan Hall ${ }^{1}$, Lars Terenius ${ }^{1}$ and Erik G Jönsson ${ }^{1}$

\begin{abstract}
Background: The serotonin (5-hydroxytryptamin; 5-HT) system has a central role in the circuitry of cognition and emotions. Multiple lines of evidence suggest that genetic variation in the serotonin transporter gene (SLC6A4; 5HTT) is associated with schizophrenia and suicidal behavior. In this study, we wanted to elucidate whether SLC6A4 variations is involved in attempted suicide among patients with schizophrenia in a Scandinavian case-control sample.

Methods: Patients diagnosed with schizophrenia from three Scandinavian samples were assessed for presence or absence of suicide attempts, based on record reviews and interview data. Seven SLC6A4 single nucleotide polymorphisms (SNPs) were genotyped in 837 schizophrenia patients and 1,473 control individuals. Association analyses and statistical evaluations were performed with the program UNPHASED (version 3.0.9).

Results: We observed an allele association between the SNP rs16965628, located in intron one of SLC6A4, and attempted suicide (adjusted p-value 0.01), among patients with schizophrenia. No association was found to a diagnosis of schizophrenia, when patients were compared to healthy control individuals.

Conclusion: The gene SLC6A4 appears to be involved in suicidal ideation among patients with schizophrenia. Independent replication is needed before more firm conclusions can be drawn.
\end{abstract}

Keywords: Suicide ideation, Serotonin transporter gene, Association, Schizophrenia

\section{Background}

The lifetime risk of committing suicide among patients with schizophrenia is approximately $5 \%[1,2]$. Also attempted suicide is common, with estimates ranging from $20 \%$ to $40 \%$ [3]. The heritable component of suicide attempt is partly related to psychiatric disorders but also partly independent of them [4-6].

The serotonin (5-hydroxytryptamin; 5-HT) system has a central role in the circuitry of cognition and emotions and exerts significant effects on anxiety, mood, impulsivity, sleep, ingestive behavior, reward systems, and psychosis [7]. Pharmacological agents targeting central 5-HT system has substantial effects on emotional behaviors

\footnotetext{
* Correspondence: eva.lindholm@igp.uu.se

${ }^{1}$ Department of Clinical Neuroscience, HUBIN Project, Karolinska Institutet and Hospital, R5:00, Stockholm, Sweden

Full list of author information is available at the end of the article
}

[8-10]. Moreover, several reports imply that 5-HT may be involved in pathophysiological events associated with suicide [11-15]. In fact, postmortem examination of suicide victims shows significantly lower serotonin transporter binding in the prefrontal cortex [16].

Epidemiological and genetic studies indicate that there is a genetic component to suicidal behavior [17]. For example, a single nucleotide polymorphism (SNP) (rs1800532, A218C) in the tryptophan hydroxylase 1 gene (TPH1), which encodes a rate-limiting enzyme involved in the development of 5-HT, was previously found to be associated with suicide or suicidal attempt $[18,19]$. The same SNP was also investigated by us in the Scandinavian case-control material used in the present study [20]. However, no association was detected between TPH1 $\mathrm{A} 218 \mathrm{C}$ and suicide attempt among the patients, although an association was found to schizophrenia. 
Another gene in the serotonin system, reported several times to be involved in the risk of attempting suicide, is the serotonin transporter gene (SLC6A4 or 5-HTT) $[11,12,19,21]$. The human SLC6A4 gene (Figure 1), located on chromosome 17q11.2, is about 39,500 base pairs long and contains 14 exons, of which exons $1 \mathrm{a}$ and $1 \mathrm{~b}$ are alternatively transcribed. The gene encodes a membrane protein that plays a major role in the regulation of synaptic serotonin concentrations by recycling serotonin from the synaptic cleft.

Results from studies of 5-HTT knockout mouse have provided important clues regarding downstream effects of altered 5-HT function on behavior and the development of the brain, such as regulation of cell proliferation, migration and differentiation of neuronal tissue $[22,23]$. Interestingly, early alterations in 5-HT availability during the development of the 5 -HT system might impact the distribution and density of specific 5-HT receptors, thereby altering the postsynaptic effects of 5 -HT on target neurons and the reactivity of these neurons to specific stimuli [24].

In recent years, five genome-wide studies analyzing suicidal behavior in patients with bipolar disorder, alcoholism and major depression identified candidate regions on chromosome 2p11-12, 2p25 and 6q25-26 [6,25-29]. As far as we know, no genes associated with suicidal behavior have been reported in these regions yet. Neither are we aware of any genome wide studies analyzing suicidal behavior in patients with schizophrenia.

In the present study, we wanted to further explore the possible involvement of the serotonin system in suicide among patients with schizophrenia, by analyzing genetic variations in the SLC6A4 gene using a Scandinavian case-control sample. Scandinavian countries are generally considered to be well suited for genetic studies, as the populations are ethnically homogeneous and only recently have been subject to non-Caucasian immigration. Seven SNPs located in the SLC6A4 gene (Figure 1), were selected and genotyped in 837 patients suffering from schizophrenia and related disorders, of which 738 had information on suicidal behavior, and in 1,473 control individuals.

\section{Methods}

\section{Clinical samples}

The clinical samples originate from the Scandinavian Collaboration on Psychiatric Etiology (SCOPE) and were collected in Denmark (DK), Norway (NO), and Sweden (SE). Affected individuals were diagnosed according to ICD-10 (DK) or DSM-III-R/DSM-IV (NO and SE). All individuals were born in Scandinavia and of Caucasian origin, and the vast majority had two Scandinavian born parents. Detailed description of the samples was reported earlier [20,30-33]. The total sample set included 837 patients, of which 734 were diagnosed with schizophrenia, 87 with schizoaffective disorder and 16 with schizophreniform disorder, and 1473 control individuals (Table 1). Patients $(\mathrm{N}=738)$ were assessed for presence or absence of suicide attempts based on record reviews (DK, SE) and interview data (NO, SE). Any previous self-harm in combination with suicidal ideation, documented or reported, was regarded as a suicide attempt. For the present analyses, subjects were divided into those who had made at least one suicide attempt and those who had not attempted suicide. The Danish Scientific Committees, the Danish Data Protection Agency, the Norwegian Scientific-Ethical Committees, the Norwegian Data Protection Agency, the Ethical Committee of the Karolinska Hospital, the Stockholm Regional Ethical Committee and the Swedish Data Inspection Board all approved the study. All participants had given informed consent prior to inclusion in the study.

\section{SNP Genotyping}

Seven SNPs in the SLC6A4 gene, previously reported to be associated with schizophrenia, were analyzed. Genomic DNA was extracted from whole blood samples, and the polymorphisms were genotyped at the SNP Technology Platform in Uppsala, Sweden (www.genotyping.se), using the Illumina BeadStation

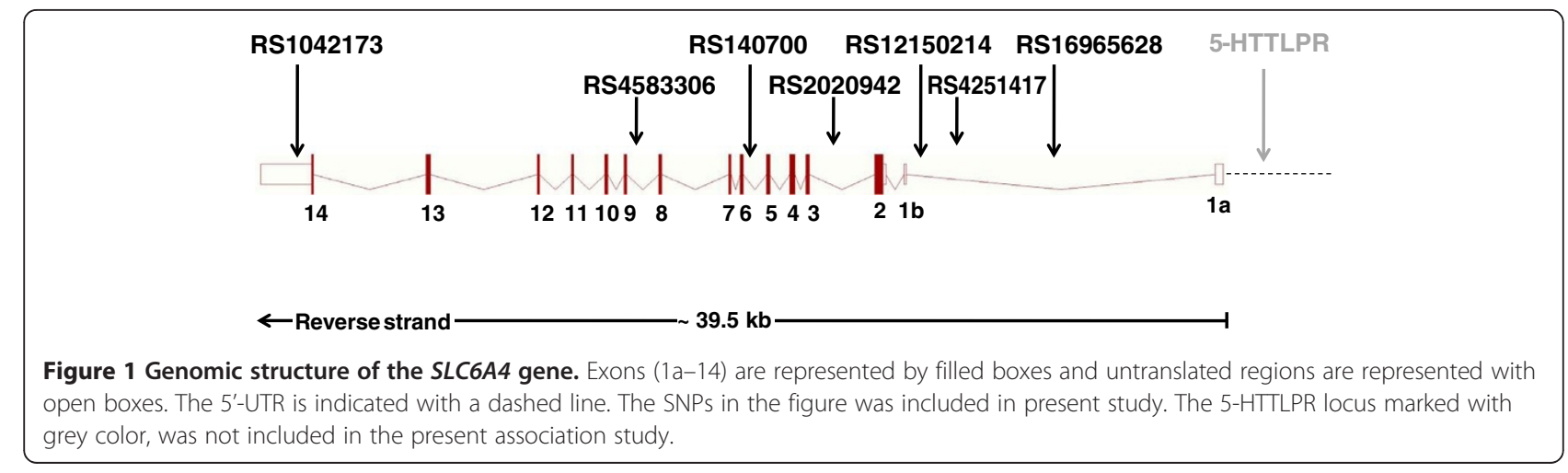


Table 1 Characteristics of Danish (DK), Norwegian (NO), and Swedish (SE) samples analyzed for association between serotonin transporter gene (SLC6A4) polymorphisms and schizophrenia and suicide attempt among affected (cases) and control individuals

\begin{tabular}{llll}
\hline Country & Characteristics & Cases & Controls \\
\hline DK & N & 420 & 1004 \\
& Gender (\% women) & 42.6 & 41.5 \\
& Age & $43.9 \pm 12.3$ & $43.2 \pm 11.8$ \\
& Age of onset & $27.2 \pm 8.9$ & \\
No of suicide attempters & 153 & \\
NO & N & 162 & 177 \\
& Gender (\% women) & 46.3 & 55.5 \\
& Age & $37.2 \pm 10.7$ & $38.7 \pm 10.3$ \\
Age of onset & $27.6 \pm 8.7$ & \\
SE & No of suicide attempters & 42 & 292 \\
& N & 255 & 37.7 \\
& Gender (\% women) & 37.2 & $50.3 \pm 10.1$ \\
& Age & $54.1 \pm 15.2$ & \\
& Age of onset & $24.6 \pm 6.9$ & \\
& No of suicide attempters & 95 & \\
& & & \\
& & &
\end{tabular}

500GX and the 1536-plex Illumina Golden Gate assay (Illumina, Inc., San Diego, CA). The sample success rate was on average $99.7 \%$ for the genotyped SNPs and the reproducibility of the genotyping was 100\% according to duplicate analysis of $2.6 \%$ of the genotypes.

\section{Statistical analyses}

Hardy-Weinberg (HW) equilibrium was tested in the control samples using Fisher's exact test as implemented in PEDSTATS [34]. Accounting for the number of tested markers, no SNP deviated significantly from HW equilibrium. Linkage disequlibrium ( $D^{\prime}$ and $R^{2}$ ) between SNP pairs, and haplotype block structure [35] were determined with Haploview 4.0 [36] (Additional file 1: Figure S1). The fixation index (FST) was calculated for each SNP separately, and all loci combined, in the control sample with FSTAT, grouping controls by country of origin. No evidence of population stratification was evident from the data: the fixation index for all combined loci was $0.003(0.001-0.005) \quad(95 \%$ bootstrap confidence interval).

Association analysis comparing allele and genotype frequencies between suicide attempters and nonattempters within the patient group and between affected individuals and controls were performed with UNPHASED (version 3.0.9) [37,38]. To account for possible population stratification and the effect of sex, we included country of origin and sex as confounding factors in the analyses. To examine whether genetic associations were homogenous, we carried out separate analyses testing if country and gender modified the association. Correction for multiple testing was done by permutation tests $(\mathrm{n}=1000)$.

\section{Results}

Out of the seven markers tested, only rs 16965628 located in the SLC6A4 gene, showed significant association to suicide attempt ( $\mathrm{P}$-value for allele association $=$ $0.00092)$ and the result remained significant also after correction for multiple testing $(\mathrm{P}$-value $=0.01)($ Table 2$)$. The minor allele $\mathrm{C}$ was underrepresented among patients with records of suicidal behavior.

We also performed genotype association analyses. However, due to the low frequency of the minor allele of rs16965628 (0.05) only one individual was CC homozygous, and consequently the same association signal was captured with the allele and the genotype test. We did not find any evidence of heterogeneity in the association signal between the three countries, nor between male and female patients for this marker (P-value $=0.75$ and 0.17 , for country and gender as modifiers, respectively). In other words, all countries and both genders contributed to the observed association between rs16965628 and suicidal behavior.

For completeness, the allele and genotype frequencies of the seven polymorphisms in patients with suicidal behavior were also contrasted against the frequencies in healthy controls. The results were similar to the comparison within the patient group, and the rs16965628 Callele was significantly lower among individuals with suicidal behavior than in the controls ( $\mathrm{p}$-value $=0.01$ after correction for multiple testing, data not shown).

Since genetic variants in the SLC6A4 were previously found to be associated with schizophrenia in other sample sets [39-44], we analyzed the association between the seven SNPs and schizophrenia in the Scandinavian case-control sample. Two SNPs were weakly associated with the disease (Table 3), but after correction for multiple testing no association was statistically significant (P-value $>0.10$ ).

We analyzed linkage disequilibrium (LD) between the polymorphisms and found two blocks. All markers, except rs16965628, were located in the observed LD blocks (Additional file 1: Figure S1). Haplotype association analyzes for the two blocks, with respect to suicidal attempt and schizophrenia susceptibility, were performed with UNPHASED. The haplotype and single marker analyzes gave similar results, i.e. there were no significant haplotype association with neither phenotype ( $\mathrm{p}>0.106$, data not shown).

\section{Discussion}

In the present study we found an association between the SLC6A4 rs16965628 polymorphism and attempted 
Table 2 Serotonin transporter (SLC6A4) single nucleotide polymorphisms (SNPs) investigated in suicidal attempters (SA) and non-suicidal (No SA) attempters with a schizophrenia diagnosis

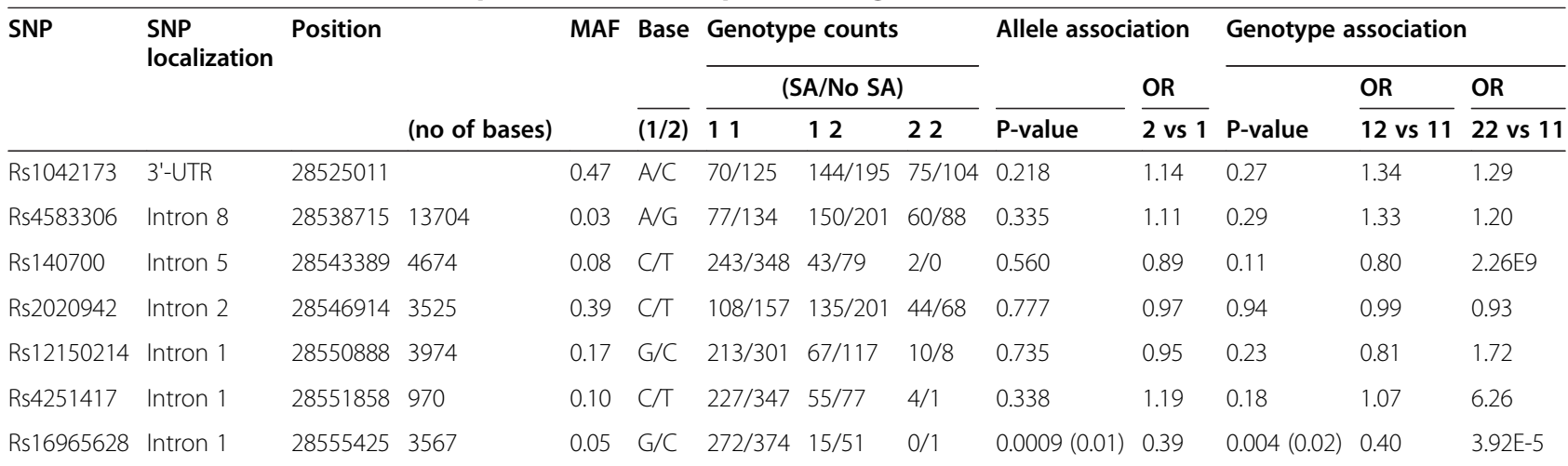

The table shows nominal allele and genotype association results with gender and country as covariates.

Chromosomal position, minor allele frequency (MAF), SNP-alleles (Base), genotype counts, P-values and odds ratios (OR) for allele and genotype association for the seven SNP markers are presented in the table. Global significant P-values are shown in parenthesis.

suicide among patients with schizophrenia ( $\mathrm{P}$-value $=$ 0.00092 and global $\mathrm{P}$-value $=0.01$ ). The odds ratio was 0.39 , indicating that the presence of the minor $\mathrm{C}$-allele protects against suicidal behavior. The rs16965628 polymorphism is located in the first intron of the SLC6A4 gene, approximately $9 \mathrm{~kb}$ downstream of promoter region. The most studied polymorphisms in the SLC6A4 gene are a 44-base pair insertion-deletion in the promoter region, generating the major L (LA and LG) and $\mathrm{S}$-alleles, and a 17-bp variable number of tandem repeats (VNTR) in the second intron [45]. During the years conflicting results have been reported regarding genetic variants in the SLC6A4 gene and suicidal ideation [46]. The ambiguous results from different studies possibly reflect insufficient sample sizes to obtain adequate statistical power, and heterogeneity between populations [47]. However, the two latest of three meta-analyses report association between SLC6A4 variants and suicidal behavior $[11,12,21]$. In the latest and largest meta-analysis, including 39 different association studies (covering all published studies up to 2006), a significant association was found between 5-HTTLPR and suicide attempts/ suicide. The L-allele was underrepresented among individuals with suicidal behavior (odds ratio was 0.88 ), suggesting that the investigated gene variant had a protective effect against suicide [11].

The mechanism behind this association is unknown, but the 5-HTTLPR polymorphism appears to affect SLC6A4 gene expression. That is, the transcription of the SLC6A4 gene is lower in the presence of the S-allele as compared to the L or the LA-alleles $[48,49]$. As mentioned in the introduction, postmortem examination of suicide victims shows significantly lower serotonin transporter binding in the prefrontal cortex [16]. Thus it is possible that the protective effect of the L-allele is the result of elevated expression of the serotonin transporter protein, leading to an overall increase in serotonin transporter binding.

Table 3 Serotonin transporter (SLC6A4) single nucleotide polymorphisms (SNPs) investigated in patients with schizophrenia and control subjects

\begin{tabular}{|c|c|c|c|c|c|c|c|c|c|c|}
\hline \multirow[t]{3}{*}{ SNP } & \multirow{3}{*}{$\begin{array}{l}\text { Base } \\
\overline{(1 / 2)}\end{array}$} & \multirow[t]{3}{*}{ MAF } & \multicolumn{3}{|c|}{ Genotype counts (schizophrenia/control) } & \multicolumn{2}{|c|}{ Allele association } & \multicolumn{3}{|c|}{ Genotype association } \\
\hline & & & \multirow{2}{*}{$\begin{array}{l}\text { Allele } 1 \\
\text { Homozyogotes }\end{array}$} & \multirow[b]{2}{*}{ Heterozygotes } & \multirow{2}{*}{$\frac{\text { Allele } 2}{\text { Homozygotes }}$} & \multirow[b]{2}{*}{ p-value } & \multirow{2}{*}{$\frac{\text { OR }}{2 \text { vs } 1}$} & \multirow[b]{2}{*}{ p-value } & \multirow{2}{*}{$\frac{\text { OR }}{12 \text { vs } 11}$} & \multirow{2}{*}{$\frac{\text { OR }}{22 \text { vs } 11}$} \\
\hline & & & & & & & & & & \\
\hline Rs1042173 & $\mathrm{A} / \mathrm{C}$ & 0.46 & $223 / 410$ & $402 / 770$ & $207 / 291$ & 0.083 & 1.11 & 0.022 & 0.93 & 1.27 \\
\hline Rs4583306 & $\mathrm{A} / \mathrm{G}$ & 0.42 & $276 / 475$ & $410 / 755$ & $173 / 237$ & 0.020 & 1.16 & 0.020 & 1.04 & 1.40 \\
\hline Rs140700 & $\mathrm{C} / \mathrm{T}$ & 0.09 & $689 / 1233$ & $140 / 221$ & $2 / 10$ & 0.435 & 1.09 & 0.171 & 1.17 & 0.39 \\
\hline Rs2020942 & $\mathrm{C} / \mathrm{T}$ & 0.14 & $313 / 528$ & $390 / 714$ & $128 / 228$ & 0.359 & 0.94 & 0.518 & 0.90 & 0.91 \\
\hline Rs12150214 & $\mathrm{G} / \mathrm{C}$ & 0.18 & 595/982 & $219 / 438$ & $21 / 46$ & 0.123 & 0.88 & 0.282 & 0.86 & 0.83 \\
\hline Rs4251417 & $\mathrm{C} / \mathrm{T}$ & 0.09 & $673 / 1204$ & $148 / 257$ & $9 / 7$ & 0.214 & 1.14 & 0.123 & 1.07 & 2.78 \\
\hline Rs16965628 & $\mathrm{G} / \mathrm{C}$ & 0.06 & 753/1310 & $77 / 152$ & $1 / 9$ & 0.192 & 0.83 & 0.125 & 0.91 & 0.19 \\
\hline
\end{tabular}

The table shows nominal allele and genotype association results with gender and country as covariates.

Nominal allele and genotype association results are reported with gender and country as covariates. MAF, minor allele frequencies in control individuals (allele 2 in the table).

Nominally significant; after correction for multiple testing using permutation test, all P- values $>0.10$. 
The relative abundance of allele transcripts of the serotonin transporter gene in human cell lines from HapMap CEPH trios, confirm the effects of 5-HTTLPR variation on the transcription of the SLC6A4 gene [50]. However, in these cell lines variation in the rs16965628 SNP was associated with considerably more transcriptional variation than the 5-HTTLPR polymorphism, and the rs16965628 C-allele was linked with increased transcription (the mean allele $\mathrm{G} / \mathrm{C}$ transcript ratio was 0.47 ) [50]. Thus we speculate that the decreased frequency of suicidal behavior among schizophrenic patients that carried the rs16965628 C-allele, observed in this study, may have been caused by increased transcription of the SLC6A4 gene and a corresponding increase in serotonin transporter binding.

The gene SLC6A4 has frequently been implicated in psychiatric disorders [51]. Meta-analyses have reported association between 5-HTTLPR S-variant - and sometimes also the 17-bp VNTR in intron 2 polymorphism and bipolar disorder [52-55], co-morbid bipolar disorder and tobacco use disorder [56], alcohol dependence $[57,58]$, major depression $[59,60]$, antidepressant-induced mania $[61,62]$, a modulation effect of 5-HTTLPR on stress and depression [63], however highly discussed [64], and anxiety-related traits [65-67], almost all disorders with elevated rates of suicide or suicide attempts. Almost all of the above mentioned disorders show elevated rates of suicide or suicide attempts. In schizophrenia, the 5-HTTLPR and 17-bp VNTR in intron 2 polymorphisms have been associated with the disorder in individual studies and the 17-bp VNTR also in several meta-analyses [68-70]. However, the latest update in the SzGene database (www.szgene.org) indicates lack of overall allele association. In previous studies, 5-HTTLPR and schizophrenia was investigated by us using Swedish case-control samples, partly overlapping with the present. The results indicated that alleles within the gene were associated with age of onset [71] and disease [44]. Other researchers reported that a haplotype, including markers 5-HTTLPR and rs16965628, was associated with obsessive compulsive disorder [72]. Furthermore, rs16965628 was found to modulate task-related activation in ventral prefrontal cortex in patients with posttraumatic stress disorder [73]. Patients with obsessive compulsive disorder and posttraumatic stress disorder are known to have an elevated risk of committing suicide [74,75].

In the present study, we did not find any significant association between genetic variants in SLC6A4 and schizophrenia although an association was found to suicide attempt. This may seem contradictive but previous epidemiological studies including monozygotic and dizygotic twins showed an elevated risk of attempting suicide even after controlling for psychiatric disorders, indicating that genetic factors independent of psychiatric disorders affect the risk of suicide attempt $[4,5]$. Thus our results do not support that the investigated SNPs are associated with a substantial increase in the disease risk in the Scandinavian population. However, even though our sample size was large, it does not have the power to unambiguously detect weak signals, and thus a true association with an odds ratio below 1.2 cannot be ruled out [76].

\section{Conclusions}

The present results provide support for an association between a relatively uncommon $S L C 6 A 4$ polymorphism and suicidal behavior among schizophrenic patients of Scandinavian origin. As the marker was not associated with the disease, the decreased risk for suicidal behavior appears to be unlinked to that of schizophrenia susceptibility. Although the estimated effect of the rs1695628 C-allele was substantial, its low frequency suggests that the potential contribution to variation in suicidal behavior in the population would be limited. Further studies in independent samples are needed to establish a link between rs1695628 and suicidal behavior in the Scandinavian and other populations.

\section{Additional file}

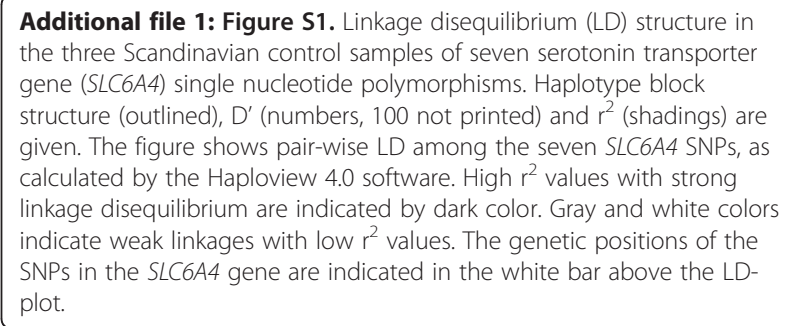

\section{Abbreviations}

SNP: Single nucleotide polymorphism; SLC6A4 (5-HTT): Serotonin transporter gene; TPH1: Tryptophan hydroxylase 1; SCOPE: Scandinavian Collaboration on Psychiatric Etiology; DK: Denmark; NO: Norway; SE: Sweden;

ICD: International Statistical Classification of Diseases and Related Health Problems; DSM: Diagnostic and Statistical Manual of Mental Disorders; DNA: Deoxyribonucleic acid; LD: Linkage Disequilibrium.

\section{Competing interests}

The authors declare that they have no competing interests.

\section{Authors' contributions}

ELC wrote the draft and coordinated the preparation of the manuscript. PS participated in the study design, performed the statistical analyses and was involved in the manuscript preparation. AR and JHT contributed with data collection (DK sample). SD participated in the study design and contributed with data collection (NO sample). IM participated in the study design, clinical characterization and contributed with data collection (NO sample). OAA participated in the study design and contributed with data collection (NO sample). TW participated in the study design and contributed with data collection (DK sample). IA, HH and LT participated in the study design and contributed with data collection (SE sample). EGJ participated in the study design, clinical characterization, contributed with data collection (SE sample) 
and was involved in the manuscript preparation. All authors contributed to and have approved the final manuscript.

\section{Acknowledgements}

We thank patients and controls for their participation and express our gratitude towards health professionals who facilitated our work. This study was financed in Denmark by grants to TW from the Lundbeck Foundation (R34-A3243); the Danish National Advanced Technology Foundation (0012009-2); the Danish Council for Independent Research in Medical Sciences (09-065634), in Norway from the Research Council of Norway (147787, 167153), the South-Eastern Norway Health Authority (Helse Sør-Øst RHF 123/ 2004), Oslo University Hospital, and University of Oslo, and in Sweden from the Swedish Research Council (K2007-62X-15077-04-1, K2007-62X-15078-04-3, K2008-62P-20597-01-3. K2010-62X-15078-07-2), the regional agreement on medical training and clinical research between Stockholm County Council and the Karolinska Institutet, the Knut and Alice Wallenberg Foundation, and the HUBIN project. We thank Alexandra Tylec for technical assistance. We also thank Kristina Larsson, Per Lundmark, Tomas Axelsson and Ann-Christine Syvänen at the SNP Technology Platform for performing the genotyping. The SNP Technology Platform is supported by Uppsala University, Uppsala University Hospital and by the Knut and Alice Wallenberg Foundation.

\section{Author details}

${ }^{1}$ Department of Clinical Neuroscience, HUBIN Project, Karolinska Institutet and Hospital, R5:00, Stockholm, Sweden. ${ }^{2}$ Research Institute of Biological Psychiatry, Copenhagen University Hospital, Mental Health Centre Sct. Hans, Roskilde, Denmark. ${ }^{3}$ TOP project, Division of Mental Health and Addiction, Oslo University Hospital \& Institute of Clinical Medicine, University of Oslo, Oslo, Norway. ${ }^{4}$ Institute of Clinical Medicine, University of Oslo, Psychiatry Section, Vinderen, Oslo, Norway. ${ }^{5}$ Department of Psychiatric Research, Diakonhjemmet Hospital, Oslo, Norway.

Received: 25 October 2011 Accepted: 25 April 2012 Published: 17 May 2012

\section{References}

1. Carlborg A, Winnerbäck K, Jönsson EG, Jokinen J, Nordström P: Suicide in schizophrenia. Expert Rev Neurother 2010, 10:1153-1164.

2. Hor K, Taylor M: Suicide and schizophrenia: a systematic review of rates and risk factors. J Psychopharmacol 2010, 24:81-90.

3. Pompili M, Amador XF, Girardi P, Harkavy-Friedman J, Harrow M, Kaplan K, Krausz M, Lester D, Meltzer HY, Modestin J, et al: Suicide risk in schizophrenia: learning from the past to change the future. Ann Gen Psychiatry 2007, 6:10.

4. Glowinski AL, Bucholz KK, Nelson EC, Fu Q, Madden PA, Reich W, Heath AC: Suicide attempts in an adolescent female twin sample. J Am Acad Child Adolesc Psychiatry 2001, 40:1300-1307.

5. Statham DJ, Heath AC, Madden PA, Bucholz KK, Bierut L, Dinwiddie SH, Slutske WS, Dunne MP, Martin NG: Suicidal behaviour: an epidemiological and genetic study. Psychol Med 1998, 28:839-855.

6. Willour VL, Seifuddin F, Mahon PB, Jancic D, Pirooznia M, Steele J, Schweizer B, Goes FS, Mondimore FM, Mackinnon DF, et al: A genome-wide association study of attempted suicide. Mol Psychiatry 2011,

7. Gingrich JA, Ansorge MS, Merker R, Weisstaub N, Zhou M: New lessons from knockout mice: The role of serotonin during development and its possible contribution to the origins of neuropsychiatric disorders. CNS Spectr 2003, 8:572-577.

8. Manuck SB, Flory JD, McCaffery JM, Matthews KA, Mann JJ, Muldoon MF: Aggression, impulsivity, and central nervous system serotonergic responsivity in a nonpatient sample. Neuropsychopharmacology 1998, 19:287-299.

9. Neumeister A: Tryptophan depletion, serotonin, and depression: where do we stand? Psychopharmacol Bull 2003, 37:99-115.

10. Neumeister A, Nugent AC, Waldeck T, Geraci M, Schwarz M, Bonne O, Bain EE, Luckenbaugh DA, Herscovitch P, Charney DS, Drevets WC: Neural and behavioral responses to tryptophan depletion in unmedicated patients with remitted major depressive disorder and controls. Arch Gen Psychiatry 2004, 61:765-773.

11. Li D, He L: Meta-analysis supports association between serotonin transporter (5-HTT) and suicidal behavior. Mol Psychiatry 2007, 12:47-54.
12. Lin PY, Tsai G: Association between serotonin transporter gene promoter polymorphism and suicide: results of a meta-analysis. Biol Psychiatry 2004, 55:1023-1030.

13. Mann JJ: Neurobiology of suicidal behaviour. Nat Rev Neurosci 2003, 4:819-828.

14. Stanley M, Mann JJ: Increased serotonin-2 binding sites in frontal cortex of suicide victims. Lancet 1983, 1:214-216.

15. Stanley M, Virgilio J, Gershon S: Tritiated imipramine binding sites are decreased in the frontal cortex of suicides. Science 1982, 216:1337-1339.

16. Mann JJ, Huang YY, Underwood MD, Kassir SA, Oppenheim S, Kelly TM, Dwork AJ, Arango $\mathrm{V}$ : A serotonin transporter gene promoter polymorphism (5-HTTLPR) and prefrontal cortical binding in major depression and suicide. Arch Gen Psychiatry 2000, 57:729-738.

17. Courtet P, Jollant F, Castelnau D, Buresi C, Malafosse A: Suicidal behavior: relationship between phenotype and serotonergic genotype. Am J Med Genet C Semin Med Genet 2005, 133C:25-33.

18. Bellivier F, Chaste P, Malafosse A: Association between the TPH gene A218C polymorphism and suicidal behavior: a meta-analysis. Am J Med Genet B Neuropsychiatr Genet 2004, 124B:87-91.

19. Rujescu D, Giegling I, Sato T, Hartmann AM, Moller HJ: Genetic variations in tryptophan hydroxylase in suicidal behavior: analysis and meta-analysis. Biol Psychiatry 2003, 54:465-473.

20. Saetre $P$, Lundmark P, Wang A, Hansen T, Rasmussen HB, Djurovic S, Melle I, Andreassen OA, Werge T, Agartz I, et al: The tryptophan hydroxylase 1 (TPH1) gene, schizophrenia susceptibility, and suicidal behavior: a multi-centre case-control study and meta-analysis. Am J Med Genet B Neuropsychiatr Genet 2009, 153B:387-396.

21. Anguelova M, Benkelfat C, Turecki G: A systematic review of association studies investigating genes coding for serotonin receptors and the serotonin transporter: II. Suicidal behavior. Mol Psychiatry 2003, 8:646-653.

22. Holmes A, Lit Q, Murphy DL, Gold E, Crawley JN: Abnormal anxiety-related behavior in serotonin transporter null mutant mice: the influence of genetic background. Genes Brain Behav 2003, 2:365-380.

23. Holmes A, Murphy DL, Crawley JN: Abnormal behavioral phenotypes of serotonin transporter knockout mice: parallels with human anxiety and depression. Biol Psychiatry 2003, 54:953-959.

24. Hariri AR, Drabant EM, Weinberger DR: Imaging genetics: perspectives from studies of genetically driven variation in serotonin function and corticolimbic affective processing. Biol Psychiatry 2006, 59:888-897.

25. Cheng R, Juo SH, Loth JE, Nee J, lossifov I, Blumenthal R, Sharpe L, Kanyas K, Lerer B, Lilliston B, et al: Genome-wide linkage scan in a large bipolar disorder sample from the National Institute of Mental Health genetics initiative suggests putative loci for bipolar disorder, psychosis, suicide, and panic disorder. Mol Psychiatry 2006, 11:252-260.

26. Hesselbrock V, Dick D, Hesselbrock M, Foroud T, Schuckit M, Edenberg H, Bucholz K, Kramer J, Reich T, Goate A, et al: The search for genetic risk factors associated with suicidal behavior. Alcohol Clin Exp Res 2004, 28:70S-76S

27. Willour VL, Zandi PP, Badner JA, Steele J, Miao K, Lopez V, MacKinnon DF, Mondimore FM, Schweizer B, McInnis MG, et al: Attempted suicide in bipolar disorder pedigrees: evidence for linkage to $2 \mathrm{p} 12$. Biol Psychiatry 2007, 61:725-727.

28. Zubenko GS, Maher BS, Hughes HB, Zubenko WN, Scott Stiffler J, Marazita ML: Genome-wide linkage survey for genetic loci that affect the risk of suicide attempts in families with recurrent, early-onset, major depression. Am J Med Genet B Neuropsychiatr Genet 2004, 129:47-54.

29. Butler AW, Breen G, Tozzi F, Craddock N, Gill M, Korszun A, Maier W, Middleton LT, Mors O, Owen MJ, et al: A genomewide linkage study on suicidality in major depressive disorder confirms evidence for linkage to 2p12. Am J Med Genet B Neuropsychiatr Genet 2010, 153:1465-1473.

30. Hansen $T$, Olsen $L$, Lindow M, Jakobsen KD, Ullum H, Jonsson $E$, Andreassen OA, Djurovic S, Melle I, Agartz l, et al: Brain expressed microRNAs implicated in schizophrenia etiology. PLoS One 2007, 2:e873.

31. Jönsson EG, Larsson K, Vares M, Hansen T, Wang AG, Djurovic S, Rönningen KS, Andreassen OA, Agartz I, Werge T, et al: Two methylenetetrahydrofolate reductase gene (MTHFR) polymorphisms, schizophrenia and bipolar disorder: an association study. Am J Med Genet B Neuropsychiatr Genet 2008, 147B:976-982.

32. Kähler AK, Djurovic S, Kulle B, Jönsson EG, Agartz I, Hall H, Opjordsmoen S, Jakobsen KD, Hansen T, Melle I, et al: Association analysis of schizophrenia 
on 18 genes involved in neuronal migration: MDGA1 as a new susceptibility gene. Am J Med Genet B Neuropsychiatr Genet 2008, 147B:1089-1100.

33. Saetre $P$, Agartz I, De Franciscis A, Lundmark P, Djurovic S, Kähler A, Andreassen $\mathrm{OA}$, Jakobsen KD, Rasmussen HB, Werge T, et al: Association between a disrupted-in-schizophrenia 1 (DISC1) single nucleotide polymorphism and schizophrenia in a combined Scandinavian casecontrol sample. Schizophr Res 2008, 106:237-241.

34. Wigginton JE, Abecasis GR: PEDSTATS: descriptive statistics, graphics and quality assessment for gene mapping data. Bioinformatics 2005, 21:3445-3447.

35. Gabriel SB, Schaffner SF, Nguyen H, Moore JM, Roy J, Blumenstiel B, Higgins J, DeFelice M, Lochner A, Faggart M, et al: The structure of haplotype blocks in the human genome. Science 2002, 296:2225-2229.

36. Barrett JC, Fry B, Maller J, Daly MJ: Haploview: analysis and visualization of LD and haplotype maps. Bioinformatics 2005, 21:263-265.

37. Dudbridge F: Pedigree disequilibrium tests for multilocus haplotypes. Genet Epidemiol 2003, 25:115-121

38. Dudbridge F: Likelihood-based association analysis for nuclear families and unrelated subjects with missing genotype data. Hum Hered 2008, 66:87-98.

39. De Luca V, Zai G, Tharmalingam S, de Bartolomeis A, Wong G, Kennedy JL: Association study between the novel functional polymorphism of the serotonin transporter gene and suicidal behaviour in schizophrenia. Eur Neuropsychopharmacol 2006, 16:268-271.

40. Dubertret C, Hanoun N, Ades J, Hamon M, Gorwood P: Family-based association study of the 5-HT transporter gene and schizophrenia. Int J Neuropsychopharmacol 2005, 8:87-92.

41. Lin C, Tang W, Hu J, Gao L, Huang K, Xu Y, He G, Liang P, Feng G, He L, Sh $Y$ : Haplotype analysis confirms association of the serotonin transporter (5-HTT) gene with schizophrenia in the Han Chinese population. Neurosci Lett 2009, 453:210-213.

42. Saiz PA, Garcia-Portilla MP, Arango C, Morales B, Alvarez V, Coto E, Fernandez JM, Bascaran MT, Bousono M, Bobes J: Association study of serotonin $2 \mathrm{~A}$ receptor $(5-\mathrm{HT} 2 \mathrm{~A})$ and serotonin transporter $(5-\mathrm{HTT})$ gene polymorphisms with schizophrenia. Prog Neuropsychopharmacol Biol Psychiatry 2007, 31:741-745.

43. Vijayan NN, Iwayama Y, Koshy LV, Natarajan C, Nair C, Allencherry PM, Yoshikawa T, Banerjee M: Evidence of association of serotonin transporter gene polymorphisms with schizophrenia in a South Indian population. J Hum Genet 2009, 54:538-542.

44. Zaboli G, Jonsson EG, Gizatullin R, De Franciscis A, Asberg M, Leopardi R: Haplotype analysis confirms association of the serotonin transporter (5-HTT) gene with schizophrenia but not with major depression. Am J Med Genet B Neuropsychiatr Genet 2008, 147:301-307.

45. Tsai SJ, Hong CJ, Liou YJ: Recent molecular genetic studies and methodological issues in suicide research. Prog Neuropsychopharmacol Biol Psychiatry 2011, 35:809-817.

46. Arango V, Huang YY, Underwood MD, Mann JJ: Genetics of the serotonergic system in suicidal behavior. J Psychiatr Res 2003, 37:375-386

47. Gonda X, Fountoulakis KN, Harro J, Pompili M, Akiskal HS, Bagdy G, Rihmer $Z$ : The possible contributory role of the $S$ allele of 5-HTTLPR in the emergence of suicidality. J Psychopharmacol 2011, 25:857-866.

48. Lesch KP, Bengel D, Heils A, Sabol SZ, Greenberg BD, Petri S, Benjamin J, Muller CR, Hamer DH, Murphy DL: Association of anxiety-related traits with a polymorphism in the serotonin transporter gene regulatory region. Science 1996, 274:1527-1531.

49. Hu XZ, Lipsky RH, Zhu G, Akhtar LA, Taubman J, Greenberg BD, Xu K, Arnold $P D$, Richter MA, Kennedy JL, et al: Serotonin transporter promoter gain-of-function genotypes are linked to obsessive-compulsive disorder. Am J Hum Genet 2006, 78:815-826.

50. Martin J, Cleak J, Willis-Owen SA, Flint J, Shifman S: Mapping regulatory variants for the serotonin transporter gene based on allelic expression imbalance. Mol Psychiatry 2007, 12:421-422.

51. Levinson DF: Meta-analysis in psychiatric genetics. Curr Psychiatry Rep 2005, 7:143-151.

52. Furlong RA, Ho L, Walsh C, Rubinsztein JS, Jain S, Paykel ES, Easton DF, Rubinsztein DC: Analysis and meta-analysis of two serotonin transporter gene polymorphisms in bipolar and unipolar affective disorders. Am J Med Genet 1998, 81:58-63.
53. Lotrich FE, Pollock BG: Meta-analysis of serotonin transporter polymorphisms and affective disorders. Psychiatr Genet 2004, 14:121-129.

54. Lasky-Su JA, Faraone SV, Glatt SJ, Tsuang MT: Meta-analysis of the association between two polymorphisms in the serotonin transporter gene and affective disorders. Am J Med Genet B Neuropsychiatr Genet 2005, 133B:110-115

55. Cho HJ, Meira-Lima I, Cordeiro Q, Michelon L, Sham P, Vallada H, Collier DA: Population-based and family-based studies on the serotonin transporter gene polymorphisms and bipolar disorder: a systematic review and meta-analysis. Mol Psychiatry 2005, 10:771-781.

56. McEachin RC, Saccone NL, Saccone SF, Kleyman-Smith YD, Kar T, Kare RK, Ade AS, Sartor MA, Cavalcoli JD, McInnis MG: Modeling complex genetic and environmental influences on comorbid bipolar disorder with tobacco use disorder. BMC Med Genet 2010, 11:14.

57. Feinn R, Nellissery M, Kranzler HR: Meta-analysis of the association of a functional serotonin transporter promoter polymorphism with alcohol dependence. Am J Med Genet B Neuropsychiatr Genet 2005, 133B:79-84.

58. McHugh RK, Hofmann SG, Asnaani A, Sawyer AT, Otto MW: The serotonin transporter gene and risk for alcohol dependence: a meta-analytic review. Drug Alcohol Depend 2010, 108:1-6.

59. Lopez-Leon S, Janssens AC, Gonzalez-Zuloeta Ladd AM, Del-Favero J, Claes SJ, Oostra BA, van Duijn CM: Meta-analyses of genetic studies on major depressive disorder. Mol Psychiatry 2008, 13:772-785.

60. Clarke H, Flint J, Attwood AS, Munafo MR: Association of the 5- HTTLPR genotype and unipolar depression: a meta-analysis. Psychol Med 2010, 40:1767-1778.

61. Daray FM, Thommi SB, Ghaemi SN: The pharmacogenetics of antidepressant-induced mania: a systematic review and meta-analysis. Bipolar Disord 2010, 12:702-706.

62. Biernacka JM, McElroy SL, Crow S, Sharp A, Benitez J, Veldic M, Kung S, Cunningham JM, Post RM, Mrazek D, Frye MA: Pharmacogenomics of antidepressant induced mania: a review and meta-analysis of the serotonin transporter gene (5HTTLPR) association. J Affect Disord 2012, 136:e21-29

63. Karg K, Burmeister M, Shedden K, Sen S: The serotonin transporter promoter variant (5-HTTLPR), stress, and depression meta-analysis revisited: evidence of genetic moderation. Arch Gen Psychiatry 2011, 68:444-454.

64. Risch N, Herrell R, Lehner T, Liang KY, Eaves L, Hoh J, Griem A, Kovacs M, Ott J, Merikangas KR: Interaction Between the Serotonin Transporter Gene (5-HTTLPR), Stressful Life Events, and Risk of Depression A Meta-analysis. Jama-Journal of the American Medical Association 2009, 301:2462-2471.

65. Schinka JA, Busch RM, Robichaux-Keene N: A meta-analysis of the association between the serotonin transporter gene polymorphism (5-HTTLPR) and trait anxiety. Mol Psychiatry 2004, 9:197-202.

66. Sen S, Burmeister M, Ghosh D: Meta-analysis of the association between a serotonin transporter promoter polymorphism (5-HTTLPR) and anxiety-related personality traits. Am J Med Genet B Neuropsychiatr Genet 2004, 127B:85-89.

67. Munafo MR, Freimer NB, Ng W, Ophoff R, Veijola J, Miettunen J, Jarvelin MR, Taanila A, Flint J: 5-HTTLPR genotype and anxiety-related personality traits: a meta-analysis and new data. Am J Med Genet B Neuropsychiatr Genet 2009, 150B:271-281.

68. Fan JB, Sklar P: Meta-analysis reveals association between serotonin transporter gene STin2 VNTR polymorphism and schizophrenia. Mol Psychiatry 2005, 10:928-938.

69. Allen NC, Bagade S, McQueen MB, loannidis JP, Kavvoura FK, Khoury MJ, Tanzi RE, Bertram L: Systematic meta-analyses and field synopsis of genetic association studies in schizophrenia: the SzGene database. Nat Genet 2008, 40:827-834.

70. Shi J, Gershon ES, Liu C: Genetic associations with schizophrenia: meta-analyses of 12 candidate genes. Schizophr Res 2008, 104:96-107.

71. Rao D, Jönsson EG, Paus S, Ganguli R, Nöthen M, Nimgaonkar VL: Schizophrenia and the serotonin transporter gene. Psychiatr Genet 1998, 8:207-212.

72. Wendland JR, Moya PR, Kruse MR, Ren-Patterson RF, Jensen CL, Timpano KR, Murphy DL: A novel, putative gain-of-function haplotype at SLC6A4 associates with obsessive-compulsive disorder. Hum Mol Genet 2008, 17:717-723.

73. Morey RA, Hariri AR, Gold AL, Hauser MA, Munger HJ, Dolcos F, McCarthy G: Serotonin transporter gene polymorphisms and brain function during 
emotional distraction from cognitive processing in posttraumatic stress disorder. BMC Psychiatry 2011, 11:76.

74. Diaconu G, Turecki G: Obsessive-compulsive personality disorder and suicidal behavior: evidence for a positive association in a sample of depressed patients. J Clin Psychiatry 2009, 70:1551-1556.

75. Panagioti M, Gooding P, Tarrier N: Post-traumatic stress disorder and suicidal behavior: A narrative review. Clin Psychol Rev 2009, 29:471-482.

76. Jönsson EG, Saetre $P$, Vares M, Andreou D, Larsson K, Timm S, Rasmussen HB, Djurovic S, Melle I, Andreassen OA, et al: DTNBP1, NRG1, DAOA, DAO and GRM3 polymorphisms and schizophrenia: an association study. Neuropsychobiology 2009, 59:142-150.

doi:10.1186/1744-9081-8-24

Cite this article as: Lindholm Carlström et al: Association between a genetic variant in the serotonin transporter gene (SLC6A4) and suicidal behavior in patients with schizophrenia. Behavioral and Brain Functions $20128: 24$.

\section{Submit your next manuscript to BioMed Central and take full advantage of:}

- Convenient online submission

- Thorough peer review

- No space constraints or color figure charges

- Immediate publication on acceptance

- Inclusion in PubMed, CAS, Scopus and Google Scholar

- Research which is freely available for redistribution 